\title{
Resistencia de Cepas STEC 0157:H7 Aisladas de Reservorio Bovino a Diferentes Agentes de Inactivación Bacteriana
}

\author{
Mariana Cap (I), Karina Moreno (I), Gerónimo Ortigoza (I), Claudio \\ Sanow (I), Sergio Vaudagna (I,II,III), Marcelo Masana (I) \\ (I) ITA, CIA, INTA - Instituto de Tecnología de Alimentos (Morón, Buenos Aires, Argentina), (II) \\ CONICET - Consejo Nacional de Investigaciones Científicas y Técnicas (Argentina), (III) UADE \\ - Universidad Argentina de la Empresa (Argentina)
}

\section{Resumo}

Escherichia coli productor de toxina Shiga serotipo O157 (STEC O157) es objeto de preocupación para la industria de alimentos, desde que en 1993 ocurrió un brote con casos de Síndrome Urémico Hemolítico en EE.UU. por consumo de hamburguesas. Este microorganismo es altamente patógeno con una baja dosis infectiva y cuyo principal reservorio es el ganado bovino. El objetivo de este estudio fue comparar la resistencia de cepas aisladas de reservorio bovino de Argentina con cepas de referencia ante diferentes factores de inactivación bacteriana. Las cepas STEC O157:H7 autóctonas empleadas fueron de materia fecal bovina (I-15) y de carcasas bovinas (I-105) en frigoríficos locales, ambas con genotipo $\mathrm{stx}_{2} \mathrm{stx}_{2 \mathrm{c}(\mathrm{vh}-\mathrm{a})} / \mathrm{rbf} \mathrm{O} 157$. Como cepa de referencia se utilizó la cepa de colección EDL 933, originalmente aislada de una hamburguesa contaminada implicada en un brote de colitis hemorrágica en EE.UU. Los agentes de inactivación y condiciones empleadas fueron: altas presiones hidrostáticas (APH) (400MPa - 5 minutos), estrés oxidativo en un medio fuertemente oxidante $\left(50 \mathrm{mM}\right.$ de $\left.\mathrm{H}_{2} \mathrm{O}_{2}\right)$, temperatura $\left(60^{\circ} \mathrm{C}\right)$, y estrés osmótico en un medio con alta presión osmótica ( $20 \%$ de $\mathrm{NaCl})$. Para cada uno de los ensayos se utilizaron cultivos en fase estacionaria resuspendidos a una concentración de $10^{8} \mathrm{UFC} / \mathrm{ml}$ en un medio apropiado para cada caso: buffer fosfato salino (PBS) para APH, caldo Tripticasa Soja (TSB, Oxoid, UK) para temperatura y alta presión osmótica, y agua destilada para el 
estrés oxidativo. El tiempo para reducir un logaritmo (TRL) en las cepas ensayadas varió entre 1,8 y 4 min. para la APH; entre 5 y 13 min. para el estrés oxidativo; entre 498 y $730 \mathrm{~min}$. para la alta presión osmótica, y entre 1,7 y 4 min. para la temperatura. Bajo todas las condiciones ensayadas, las cepas aisladas del reservorio bovino resultaron estadísticamente diferentes de las cepas de referencia, con mayores TRL para la cepa EDL 933 que para las cepas autóctonas. Estos resultados confirman la utilidad de considerar un pool de distintas cepas de STEC O157 al realizar ensayos de desafío.

Palavras-Chave: Buffer, Factores de estrés, Inactivación, STEC O157:H7, Variabilidad

Agência de Fomento: ITA-CIA-INTA 